\title{
Life cycle environmental impacts of carbonated soft drinks
}

\author{
David Amienyo • Haruna Gujba • Heinz Stichnothe • \\ Adisa Azapagic
}

Received: 30 December 2011 / Accepted: 12 June 2012 /Published online: 3 July 2012

(C) Springer-Verlag 2012

\begin{abstract}
Purpose The UK carbonated drinks sector was worth $£ 8$ billion in 2010 and is growing at an annual rate of $4.9 \%$. In an attempt to provide a better understanding of the environmental impacts of this sector, this paper presents, for the first time, the full life cycle impacts of carbonated soft drinks manufactured and consumed in the UK. Two functional units are considered: 11 of packaged drink and total annual production of carbonated drinks in the UK. The latter has been used to estimate the impacts at the sectoral level. The system boundary is from 'cradle to grave'. Different packaging used for carbonated drinks is considered: glass bottles (0.75 1), aluminium cans $(0.33 \mathrm{l})$ and polyethylene terephthalate (PET) bottles (0.5 and 21$)$.

Materials and methods The study has been carried out following the ISO 14040/44 life cycle assessment (LCA) methodology. Data have been sourced from a drink manufacturer as well as the CCaLC, Ecoinvent and Gabi databases. The LCA software tools CCaLC v2.0 and GaBi 4.3 have been used for LCA modelling. The environmental impacts have been estimated according to the CML 2001 method.

Results and discussion Packaging is the main hotspot for most environmental impacts, contributing between 59 and $77 \%$. The ingredients account between 7 and $14 \%$ mainly due to sugar; the manufacturing stage contributes 5-10\%, largely due to the energy for filling and packaging. Refrigeration of the drink at retailer increases global warming
\end{abstract}

Responsible editor: Niels Jungbluth

D. Amienyo $\cdot$ H. Gujba $\cdot$ H. Stichnothe $\cdot$ A. Azapagic $(\triangle)$

School of Chemical Engineering and Analytical Science,

The University of Manchester,

Room C16, The Mill, Sackville Street,

Manchester M13 9PL, UK

e-mail: Adisa.Azapagic@manchester.ac.uk potential by up to $33 \%$. Transport contributes up to $7 \%$ to the total impacts.

Conclusions The drink packaged in 21 PET bottles is the most sustainable option for most impacts, including the carbon footprint, while the drink in glass bottles is the worst option. However, reusing glass bottles three times would make the carbon footprint of the drink in glass bottles comparable to that in aluminium cans and 0.51 PET bottles. If recycling of PET bottles is increased to $60 \%$, the glass bottle would need to be reused 20 times to make their carbon footprints comparable. The estimates at the sectoral level indicate that the carbonated drinks in the UK are responsible for over 1.5 million tonnes of $\mathrm{CO}_{2}$ eq. emissions per year. This represented $13 \%$ of the GHG emissions from the whole food and drink sector or $0.26 \%$ of the UK total emissions in 2010 .

Keywords Carbon footprint · Carbonated soft drinks · Life cycle assessment $\cdot$ Packaging

\section{Introduction}

As shown in Fig. 1, the soft drinks sector comprises carbonated drinks, dilutables, still and juice drinks, fruit juices and bottled water (sparkling and still). In 2010, the UK sector was estimated to be worth $£ 13.9$ billion with a $4.1 \%$ growth in volume on 2009 (BSDA 2011a). At the same time, the carbonated drinks subsector was valued at $£ 8$ billion and is growing at a slightly higher rate of $4.9 \%$. With the production of 6.4 billion litres or 1031 per capita, it has a significant market share, representing $44 \%$ of the total soft drinks production; see Fig. 1 (BSDA 2011a).

Currently, it is not known how the soft drinks sector impacts on the environment apart from scant facts. For instance, it is estimated that the food and drinks industry 


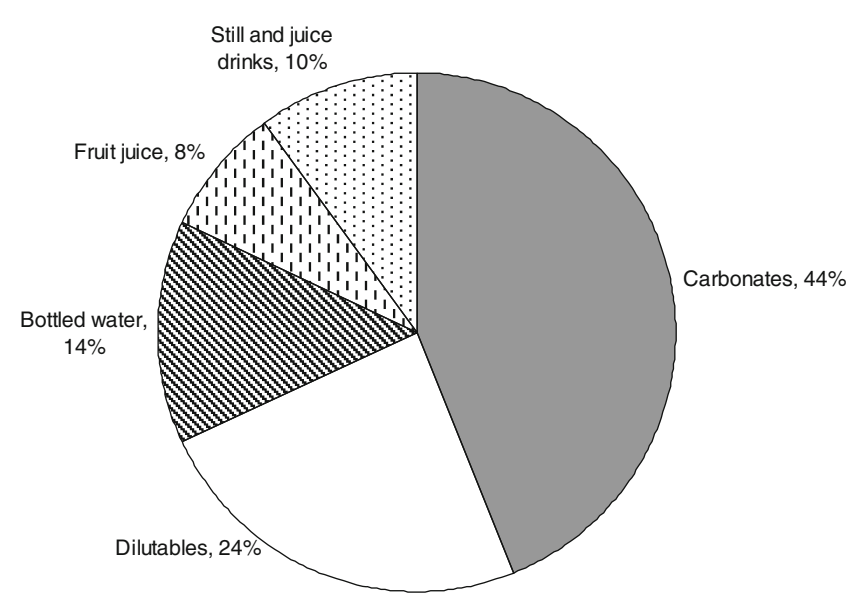

Fig. 1 The UK soft drinks sector by production volume in 2010 (BSDA 2011a, b)

contributes around $2 \%$ to the total UK greenhouse gas emissions (FDF 2008; Defra 2006) but there are no data on the contribution of carbonated drinks alone. It is also known that the drinks sector is one of the major consumers of packaging - in 2002, it accounted for over 4 million tonnes or $40 \%$ of total packaging consumed in the UK (Key Note 2003; Defra 2005), consequently also contributing to significant packaging waste streams.

While life cycle assessment (LCA) studies of beverage packaging abound (of which some more recent include
Franklin Associates 2009; Vellini and Savioli 2009; Gujba and Azapagic 2010; Pasqualino et al. 2011), there are only a couple of studies of carbonated soft drinks, both focusing solely on the carbon footprint (Coca Cola 2010; Tesco 2011). As far as we are aware, there are no full LCA studies of carbonated soft drinks in the UK.

Therefore, in an attempt to provide a better understanding of the environmental consequences of this sector, this paper presents, for the first time, the full life cycle impacts of carbonated soft drinks manufactured and consumed in the UK as well as the related impacts at the sectoral level. With respect to the latter, the paper demonstrates how the scope of the conventional product-based LCA methodology can be expanded to estimate the life cycle impacts of an industrial sector using the bottom-up approach rather than the topdown approach typically applied in input-output LCA.

\section{Goal and scope of the study}

This study has three main goals:

1. To estimate the environmental impacts and identify the 'hot spots' in the life cycle of carbonated drinks produced and consumed in the UK

2. To analyse how the environmental impacts may be affected by the type and size of different packaging typically used in the UK: glass bottles (0.75 1),
Fig. 2 The life cycle of the carbonated drink considered in this study

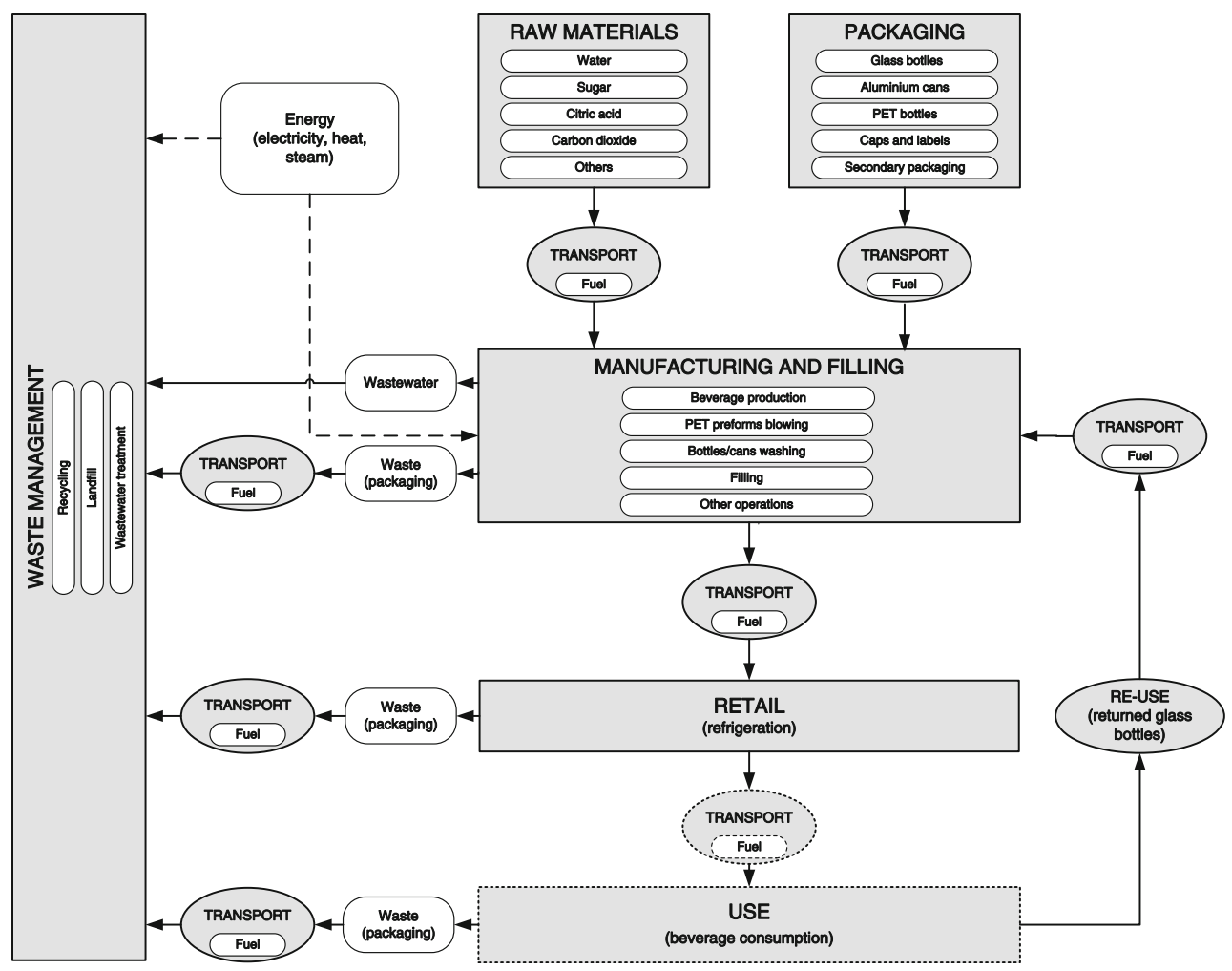


aluminium cans $(0.331)$, and polyethylene terephthalate (PET) bottles ( 0.5 and 21$)$

3. To estimate the life cycle impacts from the whole carbonated drinks sector, based on the findings from the first two goals of the study and a UK market analysis.

For the first two goals of the study, the functional unit is based on 11 of a carbonated drink. For the sectoral analysis, the functional unit considers total annual production and consumption of carbonated drinks in the UK. The results of the study are relevant to both the producers of carbonated drinks and consumers.

The life cycle of the drink is given in Fig. 2. As shown, the system boundary of the study is from 'cradle to grave', comprising the following life cycle stages:

- Raw materials (ingredients): water supply; cultivation of cane and processing of sugar; manufacture of citric acid, sodium benzoate and caffeine; carbon dioxide for carbonation

- Packaging: production of primary packaging including glass bottles, aluminium cans, PET bottles, aluminium and high-density polyethylene (HDPE) caps, kraft paper and polypropylene (PP) labels; production of secondary packaging materials including corrugated board, kraft paper, low-density polyethylene (LDPE) stretch wrap and wood pallets

- Manufacturing and filling: manufacture of the drink; blowing of PET performs; washing and filling of bottles and cans

- Retail: refrigerated storage of the drink at retailer (only as part of sensitivity analysis)

- Waste management: wastewater treatment, recycling and disposal of in-process and post-consumer waste

- Transport: transport of ingredients, packaging materials and wastes along the life cycle; transport of the drink to retailer.

The following activities are excluded from the system boundary due to a lack of data:

- packaging of the ingredients

- minor ingredients accounting for less than $1 \%$ (by weight) of the drink composition

- transport of consumers to purchase the drink and any storage at consumer.

\section{Inventory data and assumptions}

Primary production data have been obtained from a drink manufacturer, including the amounts and origin of the ingredients, the amounts of primary and secondary packaging materials, electrical energy consumed in the manufacturing
Table 1 Drink ingredients

\begin{tabular}{lcc}
\hline Ingredient & $\begin{array}{c}\text { Drink composition } \\
\text { by weight (\%) }\end{array}$ & Source of LCI data \\
\hline Water & 85 & $\begin{array}{c}\text { Water UK (2009); } \\
\text { Ecoinvent (2010) }\end{array}$ \\
$\begin{array}{l}\text { Sugar } \\
\text { Citric acid }\end{array}$ & 11 & $\begin{array}{c}\text { Ramjeawon (2004) } \\
\text { Bohnet et al. (2003); } \\
\text { Sodium benzoate }\end{array}$ \\
$\begin{array}{l}\text { Carbon dioxide } \\
\text { Colouring, flavouring } \\
\text { and additives }\end{array}$ & 0.02 & $\begin{array}{c}\text { Bohnet et al. (2003) } \\
\text { TOTAL }\end{array}$ \\
\hline
\end{tabular}

and filling stages as well as transport modes and distances. All other data have been sourced from the CCaLC (2011), Ecoinvent (2010) and Gabi (PE 2010) databases. More detail on the inventory data and their sources is provided below.

Raw materials (ingredients) Most carbonated soft drinks consist of water, sugar, carbon dioxide, an acid and a flavouring (BSDA 2011b; Key Note 2011). As shown in Table 1, the composition of the drink considered here is similar, with the main ingredients being water and sugar and small additions of citric acid, sodium benzoate and carbon

Table 2 Primary packaging

\begin{tabular}{|c|c|c|}
\hline Primary packaging type & Amount (g/l) & Source of LCI data \\
\hline \multicolumn{3}{|l|}{ Glass bottle (0.75 1) } \\
\hline $\begin{array}{l}\text { Bottle body ( } 35 \% \text { recycled } \\
\text { white glass) }\end{array}$ & 797 & Ecoinvent (2010) \\
\hline $\begin{array}{l}\text { Top ( } 84 \% \text { virgin aluminium } \\
\text { alloy and } 16 \% \text { LDPE) }\end{array}$ & 2.05 & $\begin{array}{l}\text { Ecoinvent (2010); } \\
\text { ILCD (2010); } \\
\text { Gabi (PE 2010) }\end{array}$ \\
\hline Label (kraft paper) & 1.05 & Gabi (PE 2010) \\
\hline \multicolumn{3}{|l|}{ Aluminium can $(0.331)$} \\
\hline $\begin{array}{l}\text { Can body ( } 48 \% \text { recycled } \\
\text { aluminium) }\end{array}$ & 31.2 & EAA (2008) \\
\hline $\begin{array}{l}\text { Can ends (100\% virgin } \\
\text { aluminium) }\end{array}$ & 8.3 & EAA (2008) \\
\hline \multicolumn{3}{|l|}{ PET bottle $(0.51)$} \\
\hline Bottle body (virgin PET) & 47.9 & Ecoinvent (2010) \\
\hline Top (virgin HDPE) & 6.1 & Ecoinvent (2010) \\
\hline Label (virgin PP) & 0.7 & $\begin{array}{l}\text { ILCD (2010); Gabi } \\
\quad \text { (PE 2010) }\end{array}$ \\
\hline \multicolumn{3}{|l|}{ PET bottle (2 1) } \\
\hline Bottle body (virgin PET) & 21.4 & Ecoinvent (2010) \\
\hline Top (virgin HDPE) & 1.5 & Ecoinvent (2010) \\
\hline Label (virgin PP) & 0.6 & $\begin{array}{l}\text { ILCD (2010); Gabi } \\
\quad \text { (PE 2010) }\end{array}$ \\
\hline
\end{tabular}


Table 3 Secondary packaging

\begin{tabular}{|c|c|c|}
\hline Secondary packaging type & Amount (g/l) & Source of LCI data \\
\hline \multicolumn{3}{|l|}{ Empty glass bottles ( 0.75 l) } \\
\hline Top tray (corrugated board) & 1.78 & Gabi (PE 2010) \\
\hline Stretch wrap (LDPE) & 1.23 & ILCD (2010); Gabi (PE 2010) \\
\hline Secondary label (kraft paper) & 0.002 & Gabi (PE 2010) \\
\hline Pallet (wood) & $1.36 \cdot 10^{-4}$ & Ecoinvent (2010) \\
\hline \multicolumn{3}{|l|}{ Filled bottles } \\
\hline Stretch wrap (LDPE) & 0.35 & ILCD (2010); Gabi (PE 2010) \\
\hline Crate (HDPE) & 2.18 & Gabi (PE 2010) \\
\hline Pallet (wood) & 0.62 & Ecoinvent (2010) \\
\hline \multicolumn{3}{|l|}{ Empty cans $(0.331)$} \\
\hline Banding (PET) & 0.86 & Ecoinvent (2010) \\
\hline Stretch wrap (LDPE) & 0.004 & ILCD (2010); Gabi (PE 2010) \\
\hline Secondary label (kraft paper) & 0.12 & Ecoinvent (2010) \\
\hline \multicolumn{3}{|l|}{ Filled cans } \\
\hline Stretch wrap (LDPE) & 2.07 & ILCD (2010); Gabi (PE 2010) \\
\hline Layer pads (cardboard) & 8.27 & Ecoinvent (2010) \\
\hline Case and pallet label (kraft paper) & 0.07 & Ecoinvent (2010) \\
\hline Pallet (wood) & 0.32 & Ecoinvent (2010) \\
\hline \multicolumn{3}{|l|}{ Empty PET bottles (0.5 1) } \\
\hline Crate (HDPE) & 6.06 & Gabi (PE 2010) \\
\hline Cardboard box (corrugated board) & 0.60 & Ecoinvent (2010) \\
\hline Stretch wrap (LDPE) & 0.03 & ILCD (2010); Gabi (PE 2010) \\
\hline Pallets (wood) & 0.89 & Ecoinvent (2010) \\
\hline \multicolumn{3}{|l|}{ Filled PET bottles $\left(\begin{array}{l}0.5 \\
1\end{array}\right)$} \\
\hline Stretch wrap (LDPE) & 3.39 & ILCD (2010); Gabi (PE 2010) \\
\hline Layer pads (cardboard) & 4.55 & Ecoinvent (2010) \\
\hline Case and pallet label (kraft paper) & 0.19 & Ecoinvent (2010) \\
\hline Pallet (wood) & 0.38 & Ecoinvent (2010) \\
\hline \multicolumn{3}{|l|}{ Empty PET bottles (2 1) } \\
\hline Crate (HDPE) & 3.59 & Gabi (PE 2010) \\
\hline Cardboard box (corrugated board) & 0.17 & Ecoinvent (2010) \\
\hline Stretch wrap (LDPE) & 0.01 & ILCD (2010); Gabi (PE 2010) \\
\hline Pallet (wood) & 0.06 & Ecoinvent (2010) \\
\hline \multicolumn{3}{|l|}{ Filled PET bottles (2 l) } \\
\hline Stretch wrap (LDPE) & 2.15 & ILCD (2010); Gabi (PE 2010) \\
\hline Layer pads (cardboard) & 1.14 & Ecoinvent (2010) \\
\hline Case and pallet label (kraft paper) & 0.05 & Ecoinvent (2010) \\
\hline Pallet (wood) & 0.31 & Ecoinvent (2010) \\
\hline
\end{tabular}

dioxide. Raw sugar is sourced from Mauritius and transported to the manufacturing facility in the UK where it is refined. Citric acid is imported from Colombia, while sodium benzoate is imported from The Netherlands. Liquefied carbon dioxide is sourced from different production processes as 'waste'. It is assumed that the origin of waste $\mathrm{CO}_{2}$ is biogenic, generated in fermentation processes (e.g. in whisky production). However, fossil origin of waste $\mathrm{CO}_{2}$ has also been considered within a sensitivity analysis. This is relevant for the use stage of the drink when $\mathrm{CO}_{2}$ is released (see Section 4.1).

Packaging The types and amounts of primary and secondary packaging are summarised in Tables 2 and 3 . The types of primary packaging selected for study_-glass and PET bottles and aluminium cans - are typically used for carbonated drinks in the UK. Glass bottles are assumed to contain $35 \%$ recycled content based on the UK situation for white 
Table 4 Electricity used in the manufacturing and filling stages

\begin{tabular}{|c|c|c|}
\hline Stage & Electricity $(\mathrm{Wh} / \mathrm{l})$ & Source of LCI data \\
\hline Drink manufacture & 0.1 & \\
\hline \multicolumn{3}{|l|}{ Filling and packaging } \\
\hline Glass bottle (0.75 1) & 24.8 & $\begin{array}{l}\text { ILCD (2010); Gabi } \\
\quad(\text { PE 2010) }\end{array}$ \\
\hline $\begin{array}{l}\text { Aluminium can } \\
(0.331)\end{array}$ & 24.1 & $\begin{array}{l}\text { ILCD (2010); Gabi } \\
\quad(\text { PE 2010) }\end{array}$ \\
\hline PET bottle (0.5 1) & 29.4 & $\begin{array}{l}\text { ILCD (2010); Gabi } \\
\quad(\text { PE 2010) }\end{array}$ \\
\hline PET bottle (2 1) & 11.5 & $\begin{array}{l}\text { ILCD (2010); Gabi } \\
\quad(\text { PE 2010) }\end{array}$ \\
\hline
\end{tabular}

container glass (British Glass 2009). The bottle tops are made from $84 \%$ virgin aluminium alloy and $16 \%$ LDPE, using the data from the manufacturer. The body of aluminium cans is made of $48 \%$ recycled material while the can ends are from virgin aluminium (EAA 2008). All components for the PET bottles are made from virgin plastics; tops are made of HDPE and labels of PP as specified by the manufacturer.

As shown in Table 3, the secondary packaging involves a variety of materials and systems, including corrugatedboard top trays, LDPE bags and stretch wrap, wood pallets and their kraft-paper labels, HDPE and cardboard boxes and plastic banding (straps).

Manufacturing and filling The ingredients are mixed together at the manufacturing facility and the finished product is then packaged. Table 4 shows the energy (electricity) used for these operations. The energy for filling and packaging of glass bottles includes de-palletising the bottles, washing of bottles and crates, filling, capping and labelling of the filled bottles, re-crating, re-palletising and stretch wrapping for delivery to retail. The energy for aluminium cans includes electricity for the air and belt conveyor systems, filling and sealing the filled cans. Finally, the energy consumption for the PET bottles comprises the blowing of PET pre-forms to make the bottles, washing and drying, capping, labelling and stretch wrapping as well as the use of the belt conveyor system.

Retail (refrigeration) As part of a sensitivity analysis, the carbon footprint or global warming potential (GWP) of refrigerated drink storage at retailer has been considered. The 0.331 aluminium cans and 0.5 1 PET bottles have been selected for these analyses as these drink sizes are more commonly refrigerated at retailer. As shown in Tables 5 and 6, GWP from both electricity consumption and refrigerant leakage has been considered. The following assumptions have been made:

- the refrigerant is assumed to be R404A with GWP of $3,860 \mathrm{~kg} \mathrm{CO}$ eq. $/ \mathrm{kg}$ (IPCC/TEAP 2005)

- refrigerant charge is estimated at $3.5 \mathrm{~kg} / \mathrm{kW}$ (van Baxter 2002; IPCC/TEAP 2005; DEFRA 2007; Tassou et al. 2008)

- annual refrigerant leakage rate is assumed to be $15 \%$ (Tassou et al. 2008; US EPA 2011)

- total display area of the refrigerated unit is $4.489 \mathrm{~m}^{2}$ (BSI 2005)

- the drink is refrigerated for 1 day $(24 \mathrm{~h})$ before it is sold.

Waste management As indicated in Table 7, all relevant waste streams have been considered, including inprocess packaging and drink waste as well as postconsumer waste packaging. In-process packaging waste includes bottles and cans broken during the delivery to the manufacturing site and in the filling process. This waste amounts to $0.6 \%$ of the total amount of glass

Table 5 GHG emissions from electricity consumption at retail

\begin{tabular}{|c|c|c|c|c|c|c|}
\hline $\begin{array}{l}\text { Drink } \\
\text { packaged in: }\end{array}$ & $\begin{array}{l}\text { Display cabinet } \\
\text { type }^{\mathrm{a}}\end{array}$ & $\begin{array}{l}\text { Electricity } \\
\text { consumption }{ }^{\mathrm{b}} \\
\left(\mathrm{kWh} / \mathrm{m}^{2} \text { day }\right)\end{array}$ & $\begin{array}{l}\text { Electricity } \\
\text { consumption } \\
\left(\mathrm{kWh} / \mathrm{m}^{2} \mathrm{~h}\right)\end{array}$ & $\begin{array}{l}\text { Quantity of drink } \\
\text { (litres }^{\mathrm{c}} / \mathrm{m}^{2} \mathrm{TDA}^{\mathrm{d}} \text { ) }\end{array}$ & $\begin{array}{l}\text { Electricity } \\
\text { consumption per } \\
\text { volume of drink } \\
(\mathrm{Wh} / \mathrm{h} \text { h) }\end{array}$ & $\begin{array}{l}\mathrm{GWP} \\
\text { (g CO} 2 \text { eq./1 day) }\end{array}$ \\
\hline $\begin{array}{l}\text { Aluminium } \\
\text { cans }\end{array}$ & RVC3 & 13.8 & 0.58 & 70.6 & 8.2 & 120 \\
\hline $\begin{array}{l}\text { PET bottles } \\
(0.51)\end{array}$ & RVC3 & 13.8 & 0.58 & 106.9 & 5.4 & 72 \\
\hline
\end{tabular}

${ }^{\mathrm{a}}$ RVC3: remote condensing unit, vertical, chilled

${ }^{\mathrm{b}}$ Data from Tassou et al. (2008)

${ }^{\mathrm{c}}$ Estimated by dividing the total drink volume in the display cabinet (assuming 960 units can be stored in the cabinet, gives 316.81 for aluminium cans and 4801 for PET) by the cabinet TDA $\left(4.489 \mathrm{~m}^{2}\right)$

${ }^{\mathrm{d}} T D A$ : total display area

${ }^{\mathrm{e}}$ Estimated by dividing the cabinet electricity consumption by quantity of drink 
Table 6 GHG emissions from refrigerant leakage

\begin{tabular}{|c|c|c|c|c|}
\hline Drink packaged in: & $\begin{array}{l}\text { Volume of drink } \\
\text { chilled }^{\mathrm{a}} \text { (1/year) }\end{array}$ & $\begin{array}{l}\text { Refrigerant losses per } \\
\text { year }^{\mathrm{b}}(\mathrm{g} / \text { year })\end{array}$ & $\begin{array}{l}\text { Refrigerant losses per } 1 \\
\text { of } \operatorname{drink}^{\mathrm{c}} \text { (g/l day) }\end{array}$ & $G W P^{d}$ per 1 of drink $(g / l)$ \\
\hline Aluminium cans & 115,705 & 1,050 & 0.0091 & 35.03 \\
\hline PET bottles $(0.51)$ & 175,200 & 1,050 & 0.006 & 23.13 \\
\hline
\end{tabular}

${ }^{\mathrm{a}}$ Assuming 317 and 4801 of $\mathrm{Al}$ cans and PET bottles in the cabinet, respectively; see note $\mathrm{c}$ for Table 5

${ }^{\mathrm{b}}$ Estimated by multiplying the annual refrigerant losses $(15 \%)$ by the refrigerant charge $(3.5 \mathrm{~kg} / \mathrm{kW})$ and the power of the refrigerated display unit $(2 \mathrm{~kW})$

${ }^{\mathrm{c}}$ Estimated by dividing the annual refrigerant losses by the total volume of drink chilled annually

${ }^{\mathrm{d}}$ Estimated by multiplying the refrigerant losses per litre of drink per day by the GWP emission factor for R404A of $3860 \mathrm{~kg} \mathrm{CO} 2$ eq. $/ \mathrm{kg} \mathrm{R} 404 \mathrm{~A}$

bottles, $0.63 \%$ for the aluminium cans, and 1.05 and $0.68 \%$ for the 0.5 and 21 PET bottles, respectively. For both in-process and post-consumer waste, the average UK waste management options have been assumed (see Table 7). The system has been credited for the avoided burdens from recycling of waste packaging.

Note that glass bottles in the UK are used only once and then recycled. However, as part of the sensitivity analysis,
Table 7 Waste management options
All LCI data from the Gabi database (PE 2010)

${ }^{a}$ Includes in-process and postconsumer waste; estimated based on the data provided by the drink manufacturer and post-consumer waste arisings

${ }^{b}$ Where recycled material has been used in the input packaging materials, the system has not been credited for recycling to avoid double counting

\begin{tabular}{|c|c|c|c|}
\hline Waste & Amount $(\mathrm{g} / \mathrm{l})^{\mathrm{a}}$ & Waste management ${ }^{\mathrm{b}}$ & $\begin{array}{l}\text { Source of data for waste } \\
\text { management options }\end{array}$ \\
\hline \multicolumn{4}{|l|}{ Glass bottle $(0.751)$} \\
\hline Glass & 518 & $65 \%$ Landfilled & British Glass (2009) \\
\hline \multirow[t]{2}{*}{ Aluminium } & 0.83 & $48 \%$ Recycled & EAA (2008) \\
\hline & 0.89 & $52 \%$ Landfilled & Defra (2009) \\
\hline \multirow[t]{2}{*}{ Plastics } & 0.98 & $24 \%$ Recycled & Defra (2009) \\
\hline & 3.11 & $76 \%$ Landfilled & Defra (2009) \\
\hline \multirow[t]{2}{*}{ Paper/cardboard } & 2.26 & $80 \%$ Recycled & Defra (2009) \\
\hline & 0.57 & $20 \%$ Landfilled & Defra (2009) \\
\hline Wastewater & 40.55 & Wastewater treatment & Manufacturer \\
\hline \multicolumn{4}{|l|}{ Aluminium can (0.33 1) } \\
\hline \multirow[t]{2}{*}{ Aluminium } & 3.98 & $48 \%$ Recycled & EAA (2008) \\
\hline & 20.54 & $52 \%$ Landfilled & Defra (2009) \\
\hline \multirow[t]{2}{*}{ Plastics } & 0.71 & $24 \%$ Recycled & Defra (2009) \\
\hline & 2.22 & $76 \%$ Landfilled & Defra (2009) \\
\hline \multirow[t]{2}{*}{ Paper/cardboard } & 6.77 & $80 \%$ Recycled & Defra (2009) \\
\hline & 1.69 & $20 \%$ Landfilled & Defra (2009) \\
\hline \multicolumn{4}{|l|}{ PET bottle $(0.51)$} \\
\hline \multirow[t]{2}{*}{ Plastics } & 13.95 & $24 \%$ Recycled & Defra (2009) \\
\hline & 44.17 & $76 \%$ Landfilled & Defra (2009) \\
\hline \multirow[t]{2}{*}{ Paper/cardboard } & 4.27 & $80 \%$ Recycled & Defra (2009) \\
\hline & 1.07 & $20 \%$ landfilled & Defra (2009) \\
\hline Wastewater & 267.50 & Wastewater treatment & Manufacturer \\
\hline \multicolumn{4}{|l|}{ PET bottle (2 1) } \\
\hline \multirow[t]{2}{*}{ Plastics } & 6.16 & $24 \%$ Recycled & Defra (2009) \\
\hline & 19.50 & $76 \%$ Landfilled & Defra (2009) \\
\hline \multirow[t]{2}{*}{ Paper/cardboard } & 1.09 & $80 \%$ Recycled & Defra (2009) \\
\hline & 0.27 & $20 \%$ Landfilled & Defra (2009) \\
\hline Wastewater & 66.88 & Wastewater treatment & Manufacturer \\
\hline $\begin{array}{l}\text { Waste drink and } \\
\text { wastewater from drink } \\
\text { manufacturing }\end{array}$ & 591 & Wastewater treatment & Manufacturer \\
\hline
\end{tabular}


Table 8 Transport type and distances for the ingredients, packaging and packaged drink

${ }^{\mathrm{a}}$ The transport modes and distances shown represent transport within UK. The impacts of transport of unrefined sugar from Mauritius to the UK are included with the impacts of unrefined sugar

${ }^{\mathrm{b}} \mathrm{A}$ distance of $200 \mathrm{~km}$ has been assumed for delivery of the drink to retailer for the sectoral analysis

\begin{tabular}{|c|c|c|c|c|}
\hline & Country of origin & Transport type & Distance $(\mathrm{km})$ & Source of LCI data \\
\hline \multirow[t]{2}{*}{ Sugar } & \multirow[t]{2}{*}{ Mauritius $^{\mathrm{a}}$} & Rail freight & 993 & $\begin{array}{l}\text { ILCD (2010); Gabi } \\
\quad \text { (PE 2010) }\end{array}$ \\
\hline & & Truck (40 tonne) & 534 & Gabi (PE 2010) \\
\hline \multirow[t]{2}{*}{ Citric acid } & \multirow[t]{2}{*}{ Colombia } & Container ship & 9,154 & $\begin{array}{l}\text { ILCD (2010); Gabi } \\
\quad(\text { PE 2010) }\end{array}$ \\
\hline & & Truck (40 tonne) & 378 & Gabi (PE 2010) \\
\hline \multirow[t]{2}{*}{ Caffeine } & \multirow[t]{2}{*}{ China } & Container ship & 19,953 & $\begin{array}{l}\text { ILCD (2010); Gabi } \\
\quad \text { (PE 2010) }\end{array}$ \\
\hline & & Truck (40 tonne) & 441 & Gabi (PE 2010) \\
\hline \multirow[t]{2}{*}{ Sodium benzoate } & \multirow[t]{2}{*}{ The Netherlands } & Container ship & 362 & $\begin{array}{l}\text { ILCD (2010); Gabi } \\
\quad \text { (PE 2010) }\end{array}$ \\
\hline & & Truck (40 tonne) & 441 & Gabi (PE 2010) \\
\hline Glass bottles & \multirow[t]{2}{*}{ UK } & Truck (40 tonne) & 39 & Gabi (PE 2010) \\
\hline Aluminium caps & & Bulk carrier & 378 & Gabi (PE 2010) \\
\hline Labels & UK & Truck (40 tonne) & 19 & Gabi (PE 2010) \\
\hline Aluminium cans & UK & Truck (40 tonne) & 604 & Gabi (PE 2010) \\
\hline Aluminium can ends & UK & Truck (40 tonne) & 604 & Gabi (PE 2010) \\
\hline PET preforms & UK & Truck (40 tonne) & 398 & Gabi (PE 2010) \\
\hline HDPE tops & UK & Truck (40 tonne) & 355 & Gabi (PE 2010) \\
\hline PP labels & UK & Truck (40 tonne) & 205 & Gabi (PE 2010) \\
\hline $\begin{array}{l}\text { Filled cans/bottles to } \\
\text { retail }\end{array}$ & UK & Truck (40 tonne) & $10^{\mathrm{b}}$ & Gabi (PE 2010) \\
\hline
\end{tabular}

reuse of glass bottles has also been considered. The reuse takes into account activities such as transportation, de-palletising, de-crating, de-capping, washing and inspecting the bottles during each reuse cycle. Different recycling rates for PET have also been considered within the sensitivity analysis.

Effluents from the manufacturing stage, consisting of drink wasted during the filling $(0.3 \mathrm{wt} \%)$ and water used for washing the bottles and cans, are sent to wastewater treatment which is also included in the analysis.

Transport The modes and distances for different parts of the drink system are listed in Tables 8, 9 and 10. Where no specific data have been available, a generic distance of $50 \mathrm{~km}$ has been used for post-consumer waste materials.
Table 9 Transport type and distances for in-process waste

All LCI data from the Gabi database (PE 2010)

\begin{tabular}{lllr}
\hline & Transport type & Destination country & Distance (km) \\
\hline Kraft paper labels to landfill & Truck (40 tonne) & UK & 33 \\
Aluminium caps to recycling & Truck (40 tonne) & UK & 20 \\
Plastic wastes to recycling & Truck (40 tonne) & UK & 29 \\
Corrugated board to recycling & Truck (40 tonne) & UK & 32 \\
Glass bottles to recycling & Truck (40 tonne) & UK & 80 \\
Waste PP labels to landfill & Truck (40 tonne) & UK & 33 \\
LDPE bags to landfill & Truck (40 tonne) & UK & 33 \\
Waste aluminium cans to recycling & Bulk carrier & India & 11,500 \\
Waste aluminium can ends & Bulk carrier & India & 11,500 \\
Waste PET bottles to recycling & Truck (40 tonne) & UK & 20 \\
Waste HDPE caps to recycling & Truck (40 tonne) & UK & 20 \\
Plastic wastes from the aluminium & Truck (40 tonne) & UK & 20 \\
system (LDPE and PET) to recycling & & & 32 \\
Paperboard waste from the PET systems & Truck (40 tonne) & UK & \\
to recycling & & & \\
\hline
\end{tabular}


Table 10 Transport type and distances for re-used bottles, retail and post-consumer waste

All LCI data from the Gabi database (PE 2010)

${ }^{\text {a }}$ This applies to return of reusable glass bottles from retail to the manufacturer

\begin{tabular}{|c|c|c|c|}
\hline & Transport type & Destination country & Distance $(\mathrm{km})$ \\
\hline $\begin{array}{l}\text { Glass bottles (retail to } \\
\text { manufacturer) }\end{array}$ & Truck (40 tonne) & UK & 12 \\
\hline Glass bottles to landfill & Truck (40 tonne) & UK & 20 \\
\hline Aluminium caps to landfill & Truck (40 tonne) & UK & 20 \\
\hline Kraft paper labels to landfill & Truck (40 tonne) & UK & 20 \\
\hline $\begin{array}{l}\text { Aluminium cans and can end to } \\
\text { landfill }\end{array}$ & Truck (40 tonne) & UK & 50 \\
\hline $\begin{array}{l}\text { Aluminium cans and can ends to } \\
\text { recycling }\end{array}$ & Bulk carrier & India & 11,500 \\
\hline LDPE stretch wrap to recycling & Truck (40 tonne) & UK & 50 \\
\hline LDPE stretch wrap to landfill & Truck (40 tonne) & UK & 50 \\
\hline $\begin{array}{l}\text { Cardboard to recycling } \\
\text { (aluminium cans system) }\end{array}$ & Truck (40 tonne) & UK & 50 \\
\hline $\begin{array}{l}\text { Cardboard to landfill } \\
\text { (aluminium cans system) }\end{array}$ & Truck (40 tonne) & UK & 50 \\
\hline PET to recycling & Truck (40 tonne) & UK & 50 \\
\hline PP to recycling & Truck (40 tonne) & UK & 50 \\
\hline LDPE to recycling & Truck (40 tonne) & UK & 50 \\
\hline PET to landfill & Truck (40 tonne) & UK & 50 \\
\hline PP to landfill & Truck (40 tonne) & UK & 50 \\
\hline LDPE to landfill & Truck (40 tonne) & UK & 50 \\
\hline $\begin{array}{l}\text { Cardboard to recycling } \\
\text { (PET bottles systems) }\end{array}$ & Truck (40 tonne) & UK & 50 \\
\hline $\begin{array}{l}\text { Cardboard to landfill (PET bottles } \\
\text { system) }\end{array}$ & Truck (40 tonne) & UK & 50 \\
\hline
\end{tabular}

\subsection{Global warming potential}

The results for the GWP of the carbonated drink are given in Fig. 3. The highest GWP (555 $\mathrm{g} \mathrm{CO}_{2}$ eq./l of drink) is found for the glass packaging and the lowest (151 $\mathrm{g} \mathrm{CO}_{2}$ eq.) for the 21 PET bottle. The drink in the aluminium can has the GWP of $312 \mathrm{~g} \mathrm{CO}_{2}$ eq. and in the 0.51 PET bottle $293 \mathrm{~g}$ $\mathrm{CO}_{2}$ eq. per functional unit.

As can also be seen from Fig. 3, packaging is the major 'hot spot' contributing between $49 \%$ (2 1 PET bottles) and $79 \%$ (aluminium cans) of the total GWP. This is
Fig. 3 Global warming potential of the carbonated drink for different types of packaging showing the contribution of different life cycle stages

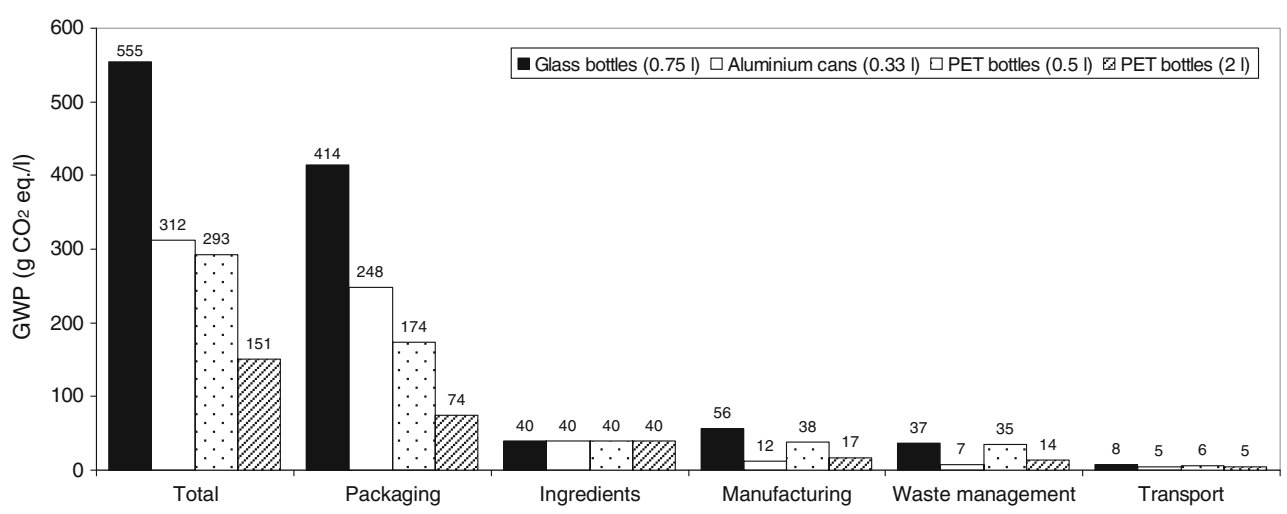


Fig. 4 Contribution of the drink ingredients to global warming potential

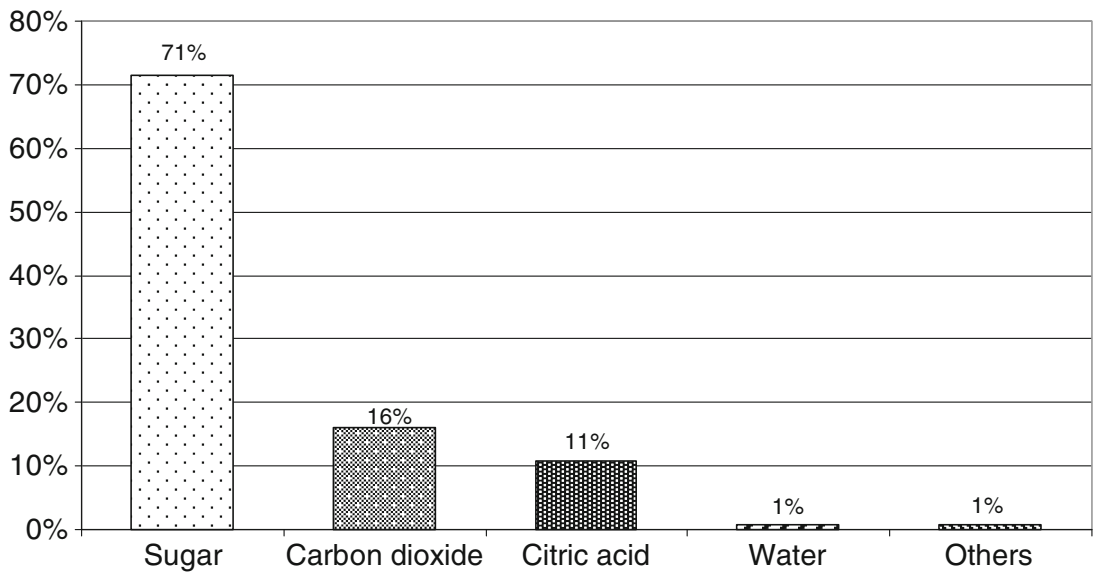

mainly (90\%) due to the primary packaging. It is interesting to note that the GWP for the drink in 0.5 1 PET bottles is by a factor of two higher than that of the 21 PET bottles due to the higher amount of packaging material needed per functional unit.

The contribution to GWP from the manufacturing stage ranges between $4 \%$ (aluminium cans) and $13 \%(0.51$ PET bottles) and is mainly due to the electricity consumption. The ingredients contribute from $7 \%$ for the glass to $26 \%$ for the PET 21 bottle. About $71 \%$ of this is from sugar production as shown in Fig. 4. This is due to the production of fertilisers and pesticides as well as cultivation and harvesting of sugar cane. The second largest contribution (16\%) to the GWP of the ingredients is by $\mathrm{CO}_{2}$ despite its accounting for only $0.6 \%$ of the drink's composition and having no impacts from its manufacture since it is produced as 'waste'; however, the energy used for its purification and liquefaction before being added to the drink adds to the impacts. It should also be noted that, due to the assumed biogenic origin of $\mathrm{CO}_{2}$, its release during the use stage is excluded from the total GWP. Assuming, on the other hand, that the $\mathrm{CO}_{2}$ is of fossil origin, its release during consumption would add around $6 \mathrm{~g} \mathrm{CO}_{2}$ eq. or $1-4 \%$ to the total GWP of the drink. Citric acid contributes a further $11 \%$ to the GWP of the ingredients mainly due to the energy intensive manufacture. Finally, although water constitutes the majority of the drink, its contribution to GWP is negligible (1\%).

The contribution of waste management is similar to that of the manufacturing stage, ranging from 2 to $12 \%$ for the aluminium can and 0.51 PET bottle, respectively. The contribution of transport is small-between $1.4 \%$ for glass and $3.4 \%$ for 21 PET bottles.

\subsubsection{Impact on GWP of refrigerated storage at retailer}

A further analysis has been carried out to assess the influence on GWP of refrigerated storage at retailer. As previously mentioned, only the aluminium cans and 0.5 1 PET bottles are considered as the drink sizes that are often refrigerated in shops. The results are presented in Fig. 5. As shown, the refrigerated storage adds $33 \%$ to the total GWP of the drink for the cans and $24.5 \%$ for the PET bottles. After packaging, this is now the second largest contributor to the total GWP of the drink. The results also indicate that $75 \%$ of the total GWP from refrigeration is contributed by electricity used to power the chiller and $25 \%$ by refrigerant leakage (see Tables 5 and 6). Furthermore, it
Fig. 5 Contribution to global warming potential of refrigerated storage of the drink in aluminium cans and PET bottles $(0.51)$. [The retail stage comprises electricity use and GHG leakage from refrigerated storage as calculated in Tables 5 and 6]

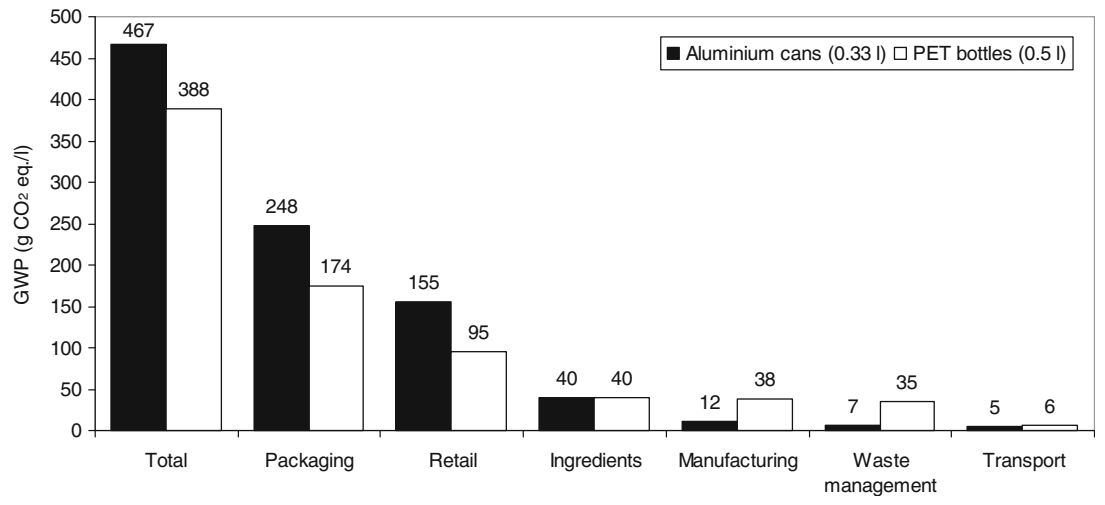


Fig. 6 The effect of glass bottle reuse on global warming potential

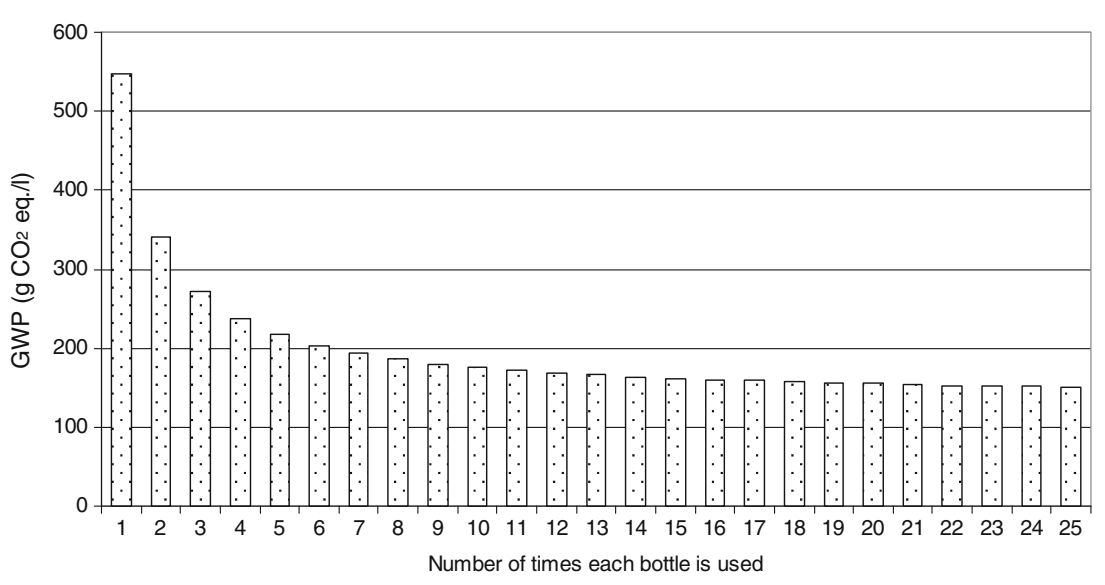

can be noticed that the GWP of the refrigerated drink in the PET bottle is $20 \%$ higher than the GWP of the drink in the aluminium can kept at the ambient temperature (see Figs. 3 and 5). Therefore, refrigerated storage at retailer should be avoided, particularly as carbonated drinks are not perishable goods. However, consumer perception and taste preference are the main drivers for refrigeration and most retailers would probably be reluctant to discontinue this practice.

\subsubsection{Impact on GWP of glass bottle reuse}

Given that the glass bottle is the most significant contributor to the total GWP, reusing the bottles has been considered to find out how the GWP would change. The results in Fig. 6 indicate that by reusing the bottle only once, the GWP would be reduced by about $40 \%$. Further savings in GWP can be achieved by increasing the number of reuses, although the benefits are not as significant after the second reuse and they gradually level off after about eight reuses. This is due to the increasing significance of bottle transport and cleaning - the benefit from the avoidance of bottle manufacture is shared between the different number of

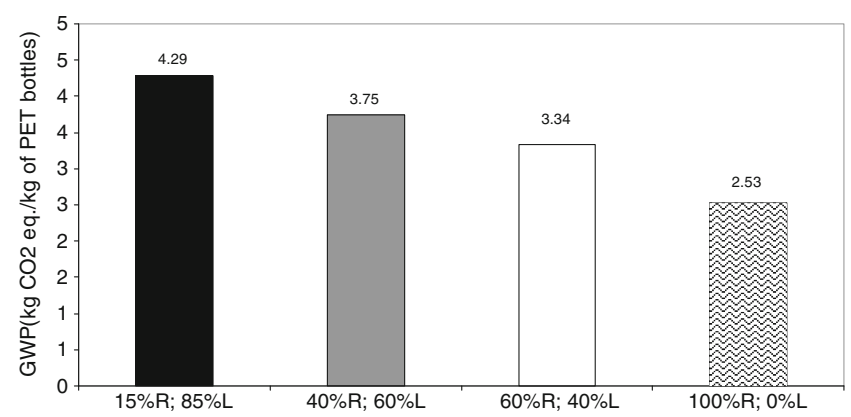

Fig. 7 The effect of different PET recycling rates on global warming potential per kg of 0.51 PET bottles (CCaLC 2011). $R$ recycling, $L$ landfill reuses, diminishing the influence of the bottle manufacture on the total GWP as the rate of reuse increases.

The results also indicate that if the glass bottles were reused three times, the GWP of the drink packaged in glass bottles would be comparable to that packaged in aluminium cans and 0.5 1 PET bottles. Thus, there is a clear case for reusing bottles between one and five times, depending on the economics of the operation (not considered here).

\subsubsection{Impact on GWP of PET recycling rates}

PET recycling rates in the UK are increasing although it is still not clear how much of PET resin is recycled back into the bottles. One study suggests that $37 \%$ of post-consumer waste PET bottles were collected in the UK in 2009 (Welle 2011), but it does not provide data on how much of that was actually recycled and particularly back into PET bottles. In the absence of the actual data, several (hypothetical) recycling rates are considered here, using the 0.51 bottle as an

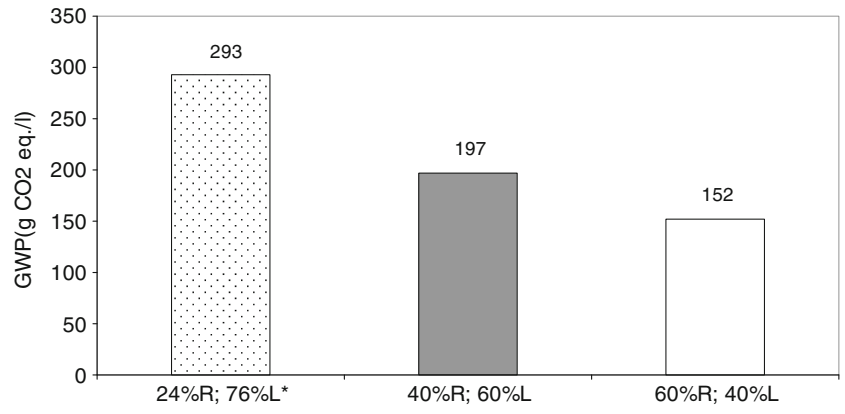

Fig. 8 The effect of different PET recycling rates on global warming potential (for the whole system with 0.51 bottles). $R$ recycling, $L$ landfill; *Reference scenario as used in the rest of the paper: $24 \% R$ and $76 \% L$ for all plastic waste (in-process and post-consumer, see Table 7); $40 \% R$ and $60 \% L$ and $60 \% R \& 40 \% L$ all post-consumer waste (bottle, tops and labels), and $24 \% R$ and $76 \% L$ for all in-process plastic waste; System expansion used to credit the system for recycling 
Fig. 9 The effect on global warming potential of drink transport from manufacturer to retailer

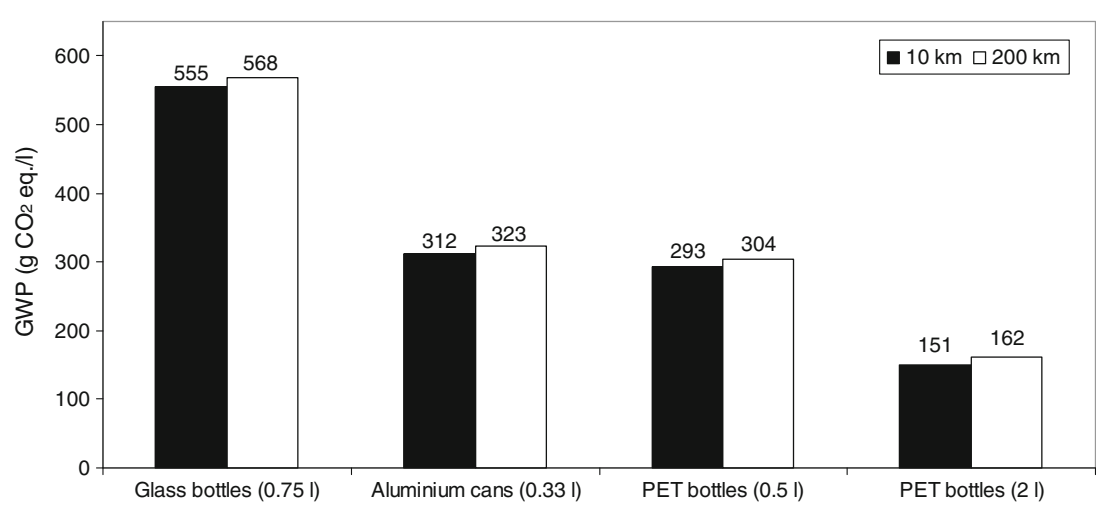

example. As shown in Fig. 7, considering only the PET bottles in isolation of the rest of the drink system, shows that increasing the recycling rates from 15 to $100 \%$ reduces GWP by up to $40 \%$ per kilogram of PET bottles. Similar, although slightly lower, savings are achieved at the whole systems level (i.e. the life cycle of the drink). For example, increasing the PET bottles recycling rate to $40 \%$ from the UK average for plastics recycling of $24 \%$ (as assumed in this study; see Table 7), reduces the GWP for the whole system by $32 \%$, from 293 to $197 \mathrm{~g} \mathrm{CO}_{2}$ eq./1 (Fig. 8). Increasing recycling to $60 \%$ reduces the total GWP of the carbonated drink by a half compared to the current recycling rate. This would also mean that the GWP of the drink in the 0.51 PET bottle would be half that of the aluminium can (152 $\mathrm{g} \mathrm{CO}_{2}$ eq./1 compared to $312 \mathrm{~g} \mathrm{CO}_{2}$ eq./1, respectively; see Figs. 3 and 8). At the same time, glass bottles would have to be reused around 20 times to make them comparable to a $60 \%$ recycled PET bottle. Therefore, the benefits of PET recycling are clear and should be increased as much as economically feasible (and subject to the law on recycling of food packaging).

\subsubsection{Impact on GWP of drink transport}

For the drink considered in this study, the actual distance travelled from the manufacturer to retailer is $10 \mathrm{~km}$. It is not known if this is a representative average distance at the sectoral level as these data are not available. Thus, the influence of this parameter on the GWP of the drink has been considered assuming a (much longer) distance of $200 \mathrm{~km}$. As shown in Fig. 9, the results indicate that the GWP would increase between $2.3 \%$ for glass bottles to $6.9 \%$ for 21 PET bottles. Therefore, the impact on GWP of drink transport would remain relatively small even for much larger manufacturerretailer distances than considered in this study.

\subsubsection{Comparison of GWP results with other studies}

The results for GWP are compared in Fig. 10 to the other two UK studies of carbonated soft drinks mentioned in Section 1 (Tesco 2011; Coca Cola 2010). As can be seen, the results differ but, as the composition and the breakdown of the results for these two drinks are not disclosed, it is not possible to determine the exact reasons for these differences. In any case, the results will be influenced by the types and sources of ingredients, background energy mixes, transport distances, waste management options and whether the drinks are refrigerated, none of which is known for the Tesco and Coca Cola studies. With respect to refrigeration, if this is included in the Tesco and Coca Cola studies, then the results are more comparable to this study.

Nevertheless, all three studies show the same trends with respect to the types of packaging. For example, for all drink types, GWP is higher for the aluminium cans than for PET bottles. Moreover, similar to the current study, the Coca
Fig. 10 Comparison of global warming potential estimated in the current work with other studies

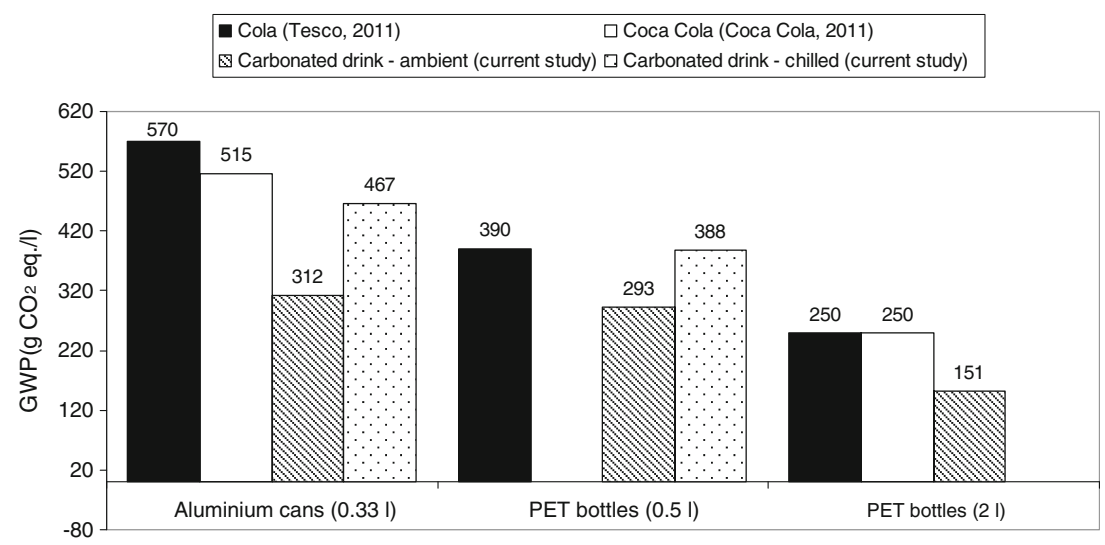




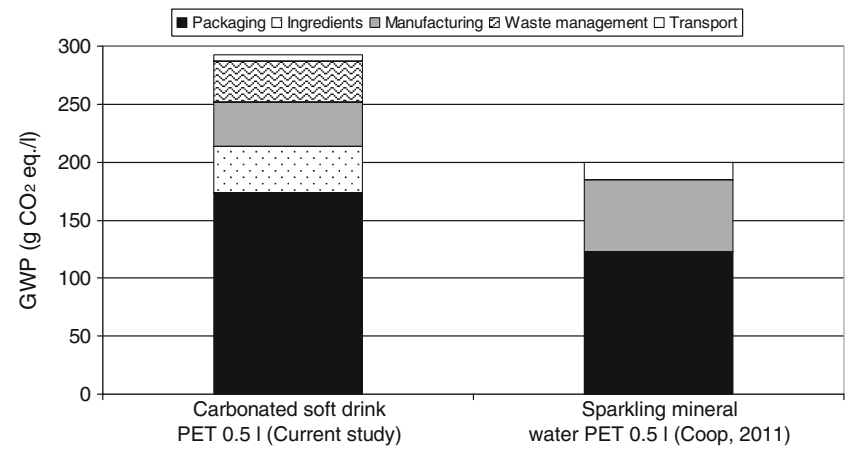

Fig. 11 Comparison of global warming potential estimated in the current work with sparkling mineral water

Cola and Tesco studies show that packaging is the main contributor to GWP, accounting between 30 and $70 \%$ of the total GWP.

A further comparison has been made with a study of carbonated (sparkling) mineral water in 0.51 PET bottles carried out in Italy (Coop 2011). Although two distinct product categories, carbonated drinks and sparkling mineral water share carbon dioxide as a common ingredient (apart from water which is also common to all other drinks). Therefore, it may be interesting to compare their GWP. As shown in Fig. 11, sparkling water has a lower GWP than the carbonated drink ( $200 \mathrm{~g} \mathrm{CO}_{2}$ eq./l compared to $293 \mathrm{~g}$ ), due to different factors, including the additional ingredients in the carbonated drink, weight of the PET bottles $(54.7 \mathrm{~g}$ for the drink compared to $39.2 \mathrm{~g} / \mathrm{l}$ for the water), different background energy mixes, transport distances, end of life waste management, etc. However, similar to the current study, primary packaging is the major contributor to the GWP of sparkling water, accounting for $55 \%$ of the total.

\subsection{Other environmental impacts}

As shown in Fig. 12, the drink packaged in 21 PET bottle has the lowest impacts for seven out of 10 impacts considered: primary energy demand (PED), abiotic depletion (ADP), acidification (AP), human toxicity (HTP), freshwater and marine aquatic toxicity (FAETP and MAETP) and photochemical oxidant creation (POCP) potentials. The aluminium can is the best option for the remaining three impacts: eutrophication (EP), terrestrial ecotoxicity (TETP) and ozone depletion.

The glass bottle, on the other hand, is the worst option for six impact categories: PED, ADP, AP, HTP, TETP and POCP. The aluminium cans have the highest HTP and MAETP while the 0.51 PET bottles have the highest EP and FAETP. The

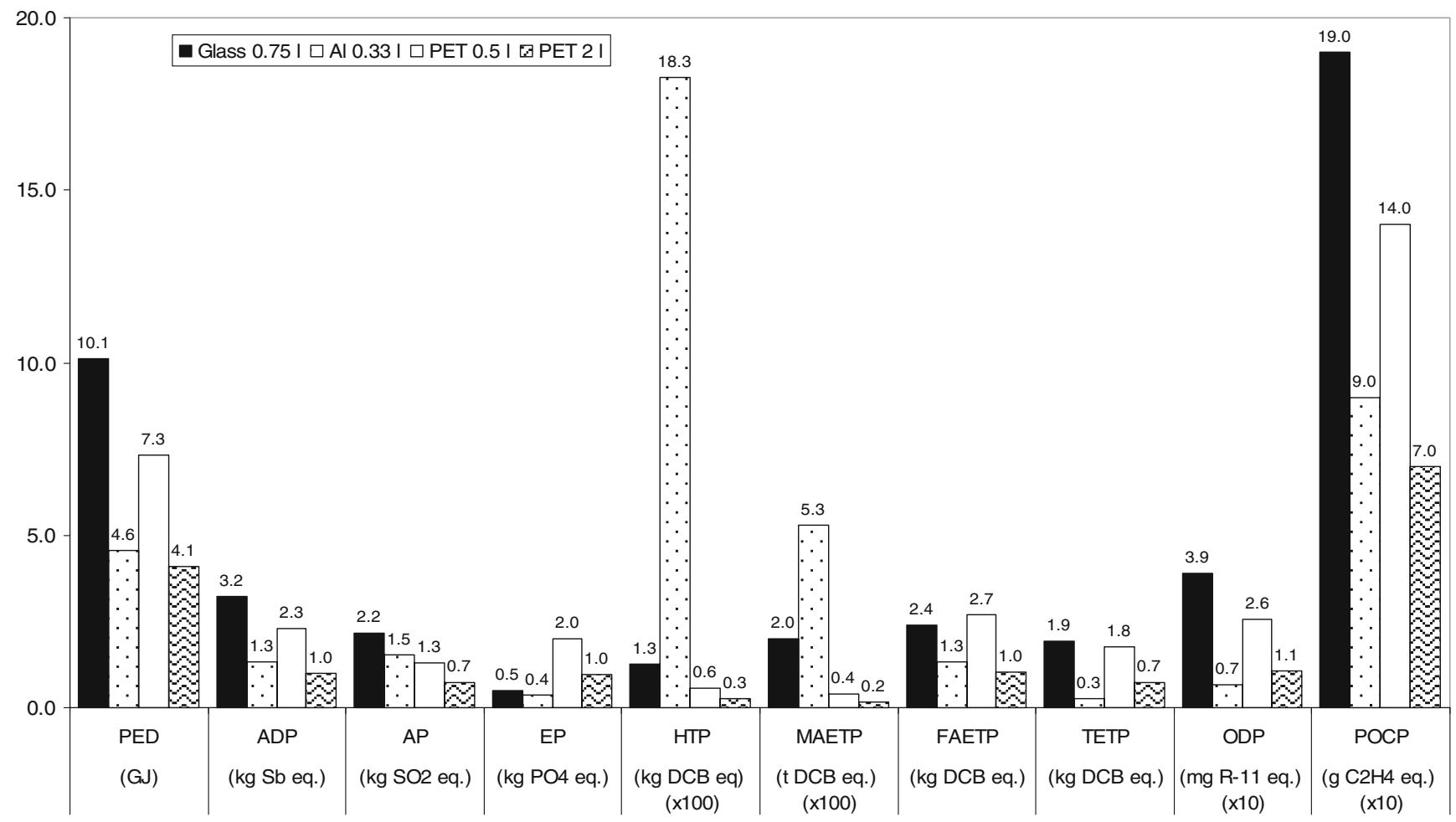

Fig. 12 Environmental impacts (other than GWP) per $1000 \mathrm{~L}$ of carbonated drink. $P E D$ primary energy demand, $A D P$ abiotic depletion potential, $A P$ acidification potential, $E P$ eutrophication potential, $H T P$ human toxicity potential, MAETP marine aquatic eco-toxicity

potential, FAETP freshwater eco-toxicity potential, TETP terrestrial eco-toxicity potential, $O D P$ ozone depletion potential, $P O C P$ photochemical oxidant creation potential 
Fig. 13 Contribution of different life cycle stages to the environmental impacts of the drink in glass bottles

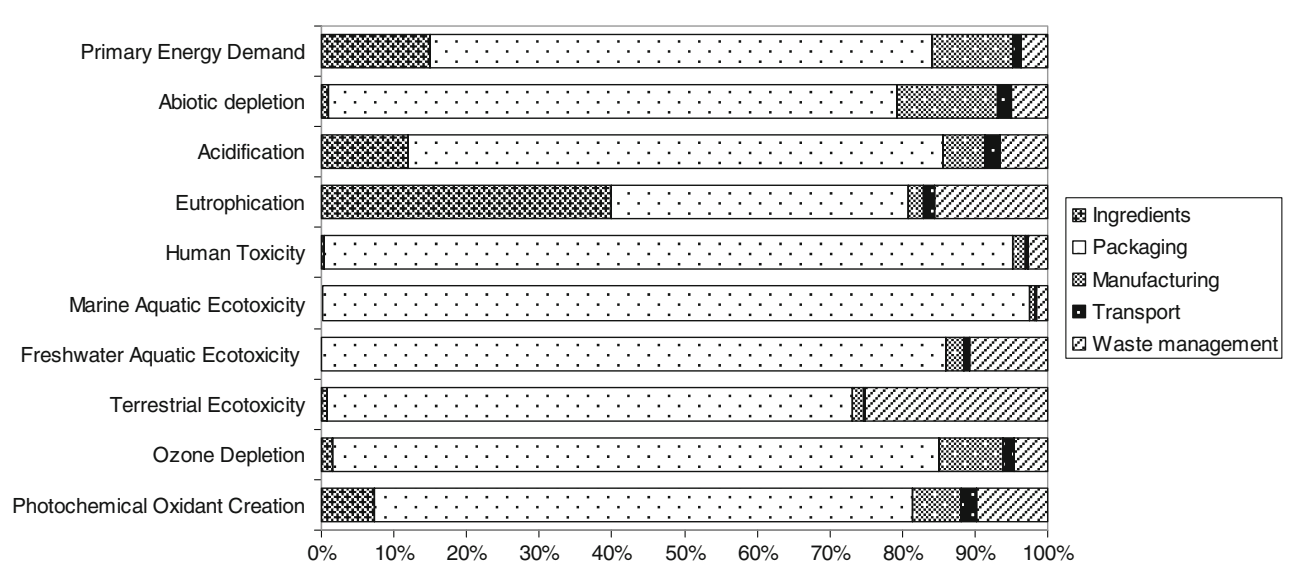

HTP from aluminium cans is particularly high (14 times higher than the next worst option, glass) - this is due to the emissions of polyaromatic hydrocarbons (PAH) from the cans production which contributes to $97 \%$ of this impact.

The life cycle stage contributions to these impacts are shown in Figs. 13, 14 and 15. Similar to GWP, the packaging stage is the major 'hot spot' for all the impacts except for EP where the ingredients and waste management are also significant. This is due to the chemical oxygen demand and nitrogen emissions to water from sugar production.

\subsection{Environmental impacts of the UK carbonated soft drinks sector}

As previously mentioned, the formulation of the carbonated soft drink considered here is similar to other carbonated soft drinks for over $95 \%$ of the ingredients (BSDA 2011b; Key Note 2011). Therefore, to estimate the potential environmental impacts of the carbonated drinks sector in the UK, the findings of this study have been extrapolated to the sectoral level using a bottom-up approach which combines the product-based LCA methodology with market analysis. This is in contrast to the top-down, input-output approach sometimes used in LCA for these purposes. The analysis focuses on the domestic production and consumption of carbonated soft drinks in the UK; the impacts of drinks destined for export are not considered.

As mentioned previously, 6.4 billion litres of carbonated soft drinks were produced in the UK in 2010 (BSDA 2011a). Of this amount, 57, 26 and $3 \%$ were packaged in PET, cans and glass, respectively, while the remaining $14 \%$ were consumed from dispensers and in other (unspecified) packaging formats. Considering only the drinks packaged in PET, cans and glass bottles ( $86 \%$ of the total UK production), the estimated life cycle environmental impacts are given in Fig. 16. For example, the carbonated drinks in the UK were responsible for over 1.5 million tonnes of $\mathrm{CO}_{2}$ eq. emissions in 2010. This represents $13 \%$ of the GHG emissions from the whole food and drink sector ${ }^{1}$ or $0.26 \%$ of the UK total emissions in $2010 .^{2}$ Although the estimates for the GHG emissions are not directly comparable as in one case they represent the life cycle emissions (for the drinks) and mainly direct emissions (food and drink sector and UK emissions), they are nevertheless an indication of the significance of the sector's contribution to the total GHG emissions.

It can also be inferred from Fig. 16 that drinks packaged in aluminium cans contribute around $36 \%$ of the total GWP, although only $26 \%$ of the drinks are packaged in the cans. Similarly, drinks in glass bottles contribute proportionally much more than their market share- $7 \%$ compared to $3 \%$. These contributions would change if PET recycling and glass bottle reuse rates increased. For example, recycling $60 \%$ of PET bottles would roughly half the emissions from the drink in this packaging type (see Fig. 8), saving around 445,000 tonnes of $\mathrm{CO}_{2}$ eq./year or $30 \%$ of the total emissions from the sector (based on the average results for 0.5 and 21 PET bottles given in Fig. 16). By comparison, reusing glass bottles up to three times would half the emissions from the drink in glass bottles but would save 'only' $50,000 \mathrm{t} \mathrm{CO}_{2}$ eq./year or $3 \%$ of the total sectoral emissions.

While it is difficult to put the other environmental impacts in context, it can be noticed in Fig. 17 that human and marine aquatic toxicity are disproportionately higher for the aluminium cans than PET bottles, compared to their market share. As mentioned before, this is due to the high emissions of PAH and hydrogen fluoride, respectively. PET bottles, on the other hand, contribute a much higher eutrophication, terrestrial toxicity and ozone layer depletion than their market share would suggest. However, similar to GWP,

\footnotetext{
${ }^{1}$ Estimated based on the contribution of the food and drink sector of $2 \%$ to total UK GHG emissions (FDF 2008; Defra 2006).

${ }^{2}$ UK GHG emissions in 2010 are estimated at 582.4 million tonnes $\mathrm{CO}_{2}$ eq. (DECC 2011).
} 
Fig. 14 Contribution of different life cycle stages to the environmental impacts of the drink in aluminium cans

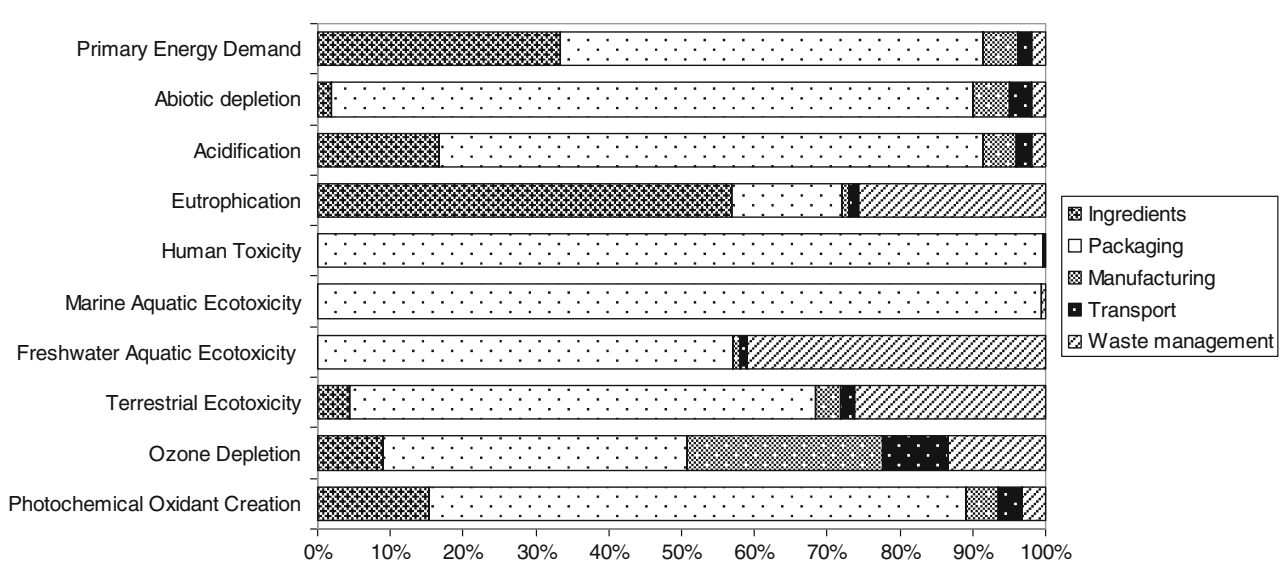

these impacts could also be reduced if the recycling rates of PET increased.

\section{Conclusions}

The life cycle environmental impacts of a carbonated drink have been estimated considering four packaging options: 0.751 glass bottles, 0.331 aluminium cans, 0.5 and 21 PET bottles. It has been found that, under the assumptions made in this study, the drink packaged in 21 PET bottle has the lowest impacts for most impact categories, including global warming potential. Glass bottle is the least preferred option for most impacts.

The results suggest that packaging is a major 'hot spot' contributing between 59 and $77 \%$ to the impacts. The ingredients account for $7-14 \%$ of the total impacts mainly due to sugar, and the manufacturing stage contributes 5-10\% due to the energy used for filling and packaging. Despite the significant transport distances involved in the supply chain, transport contributes only $1-3 \%$ to the total impacts demonstrating again that 'food miles' are typically not a significant issue. Even at much longer manufacturer-retailer distances $(200 \mathrm{~km}$ compared to $10 \mathrm{~km}$ assumed in the study), the overall contribution of transport is below $7 \%$.

The results also show that recycling $40-60 \%$ of PET bottles could reduce GWP of the drink by $32-48 \%$. Reusing glass bottles would reduce GWP by up to 2.5 times. Refrigerated storage at retailer adds around $33 \%$ and $24.5 \%$ to GWP for the cans and PET bottles, respectively, and should be avoided particularly as carbonated drinks are not perishable goods.

The analysis at the sectoral level indicates that, on a life cycle basis, carbonated soft drinks emitted over 1.5 million tonnes of $\mathrm{CO}_{2}$ eq. in 2010 . This represents roughly $13 \%$ of the greenhouse gas emissions from the UK food and drink sector. Drinks packaged in aluminium cans contribute $36 \%$ of the total GWP from the carbonated soft drinks sector, although only $26 \%$ of the drinks are packaged in the cans. Similarly, drinks in glass bottles contribute to GWP proportionally much more than their market share: $7 \%$ compared to $3 \%$, respectively. Recycling $60 \%$ of PET bottles would save around 445,000 tonnes of $\mathrm{CO}_{2}$ eq./year or around $30 \%$ of the total emissions from the sector. Reusing glass bottles up to three times would save $50,000 \mathrm{t} \mathrm{CO}_{2}$ eq./year or $3 \%$ of the total sectoral emissions.
Fig. 15 Contribution of different life cycle stages to the environmental impacts of the drink in PET bottles (average for 0.5 and 21 bottles)

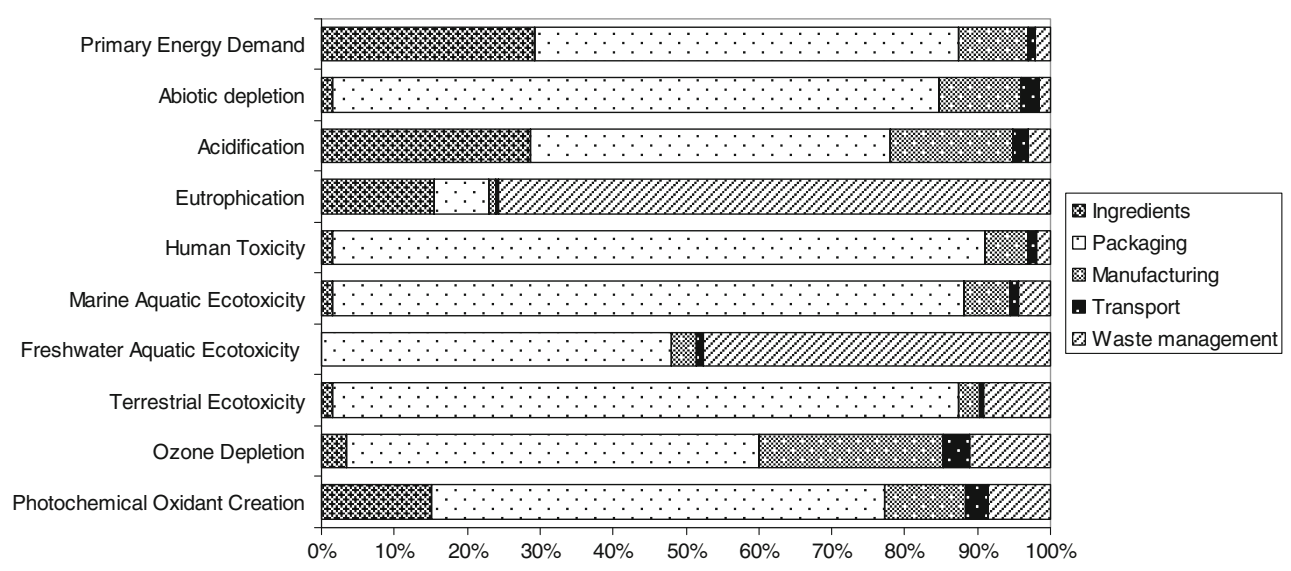




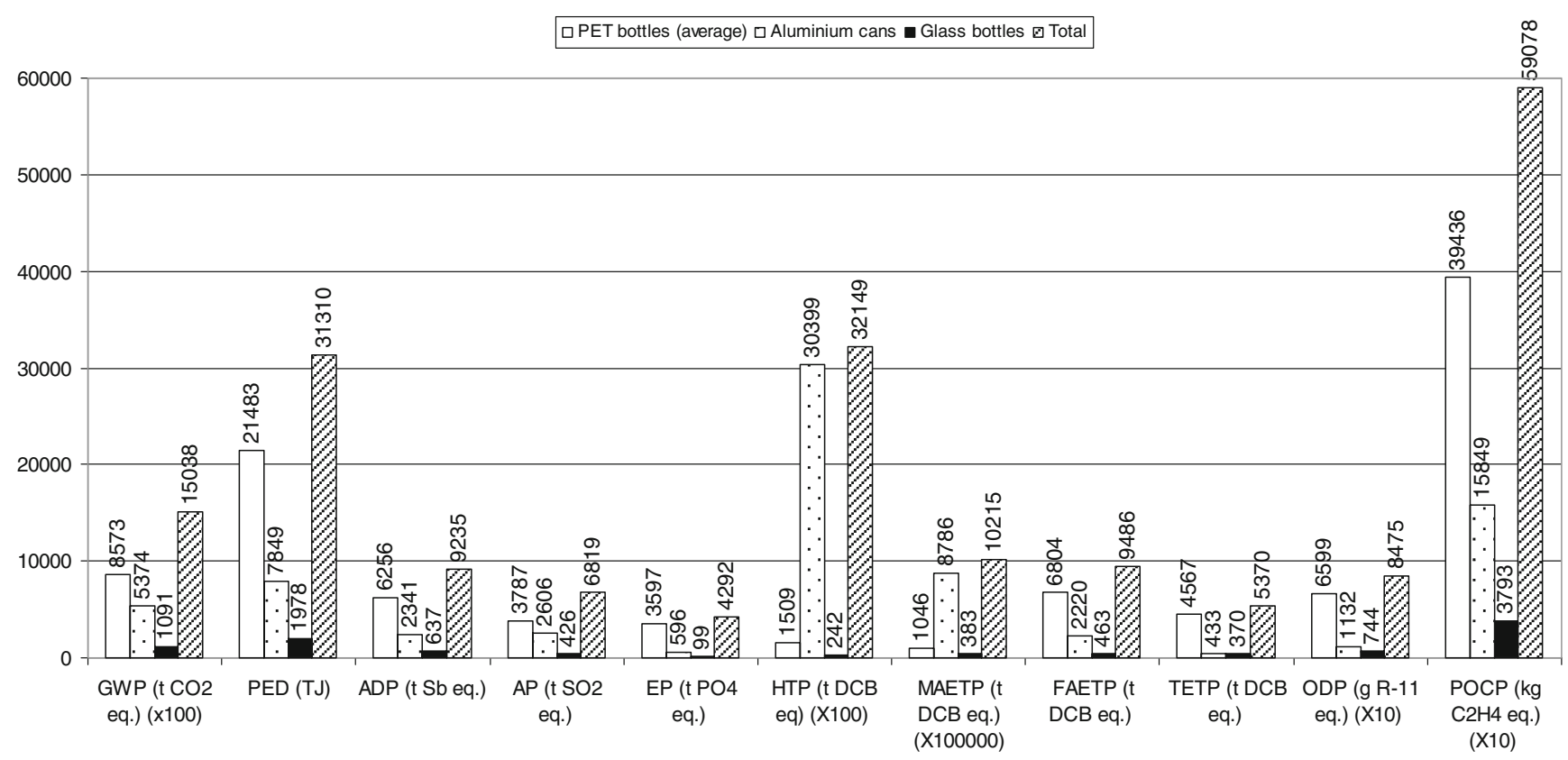

Fig. 16 Life cycle environmental impacts of carbonated drinks in the UK. [Estimates based on the production volumes and market share in 2010. All impacts expressed per year. For definition of impact categories, see Fig. 12. Some impacts have been scaled to fit on the graph. To

With respect to the other impacts, human and marine aquatic toxicity are disproportionately higher for the aluminium cans than PET bottles compared to their market share. PET bottles, on the other hand, contribute a much higher eutrophication, terrestrial toxicity and ozone layer depletion than their market share would suggest. Similar to GWP, these impacts could also be reduced if the recycling rates of PET increased. obtain the original value for a scaled impact, its value should be multiplied by the factor shown in brackets. Average distance of $200 \mathrm{~km}$ assumed for transportation of drinks from manufacturer to retailer.]

The results for the carbonated soft drink considered here are based on direct industrial data and high-quality background LCI data so that the confidence in the results is high. Where there were uncertainties in the data, these were addressed by a range of sensitivity analyses to improve the confidence in the results. However, the results of the sectoral analysis should be interpreted with care as they have been extrapolated based on one type of the carbonated drink,

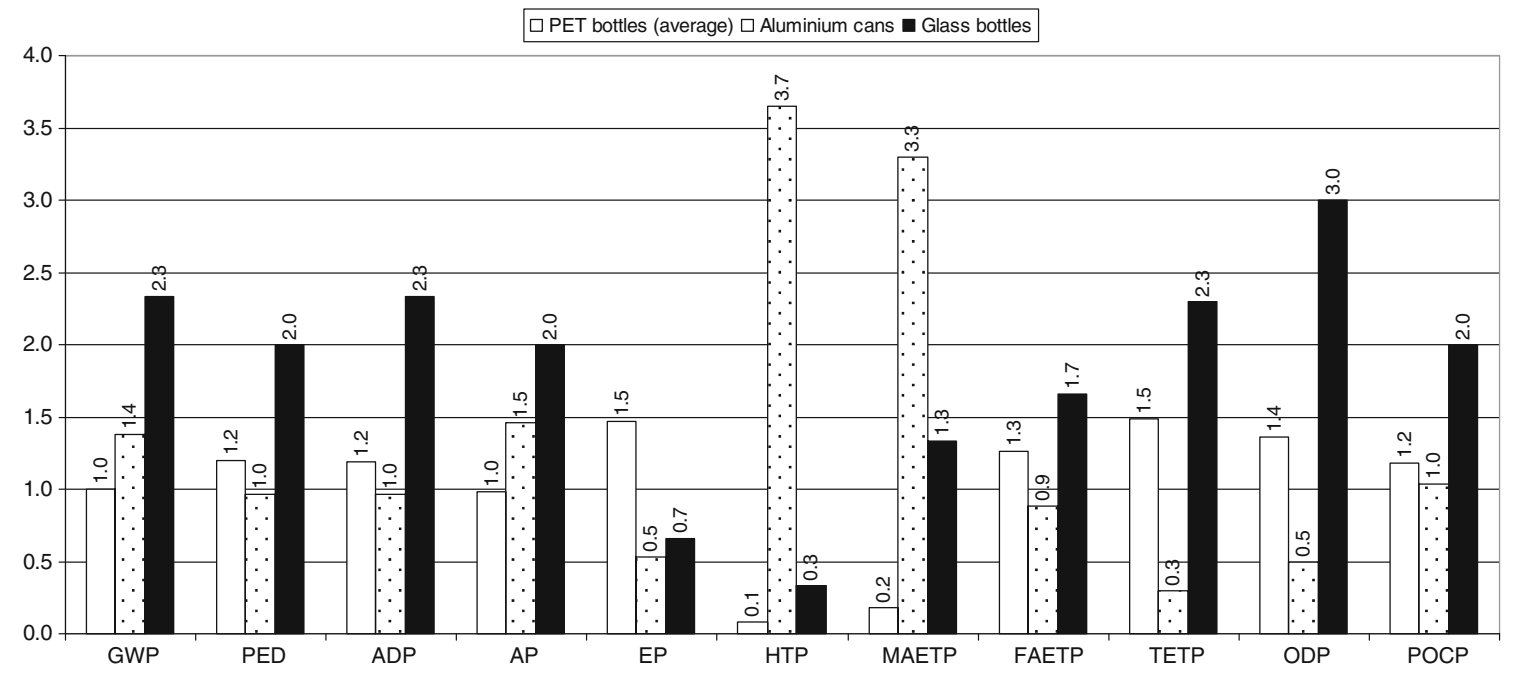

Fig. 17 Comparison of environmental impacts for different types of packaging relative to their market share. [Estimates based on the production volumes and market share in 2010 . The values represent the ratio of the impact for each packaging type and its market share of $57 \%$ for PET, $26 \%$ for aluminium cans and $3 \%$ for glass bottles.] 
albeit with a $95 \%$ composition similar to that of the other carbonated soft drinks. It is therefore recommended that further work be carried out for a range of carbonated drinks to improve the certainty of the estimates of the life cycle environmental impacts from this sector.

Acknowledgments This work has been funded by EPSRC within the $\mathrm{CCaLC}$ project (grant no. EP/F003501/1). This funding is gratefully acknowledged. The authors are also grateful to Professor Savvas Tassou from Brunel University for his advice related to refrigeration.

\section{References}

Bohnet M, Brinker CJ, Cornils B (eds) (2003) Ullmann's encyclopaedia of industrial chemistry. Wiley, New York

British Glass (2009) Recycled content. British Glass: Sheffield. www.britglass.org.uk/publications

BSDA (2011a) The 2011 UK soft drinks report. British Soft Drinks Association: London. www.britishsoftdrinks.com/PDF/2011\% 20 soft $\% 20$ drinks $\% 20$ report.pdf

BSDA (2011b) Ingredients of soft drinks. British Soft Drinks Association: London. www.britishsoftdrinks.com/default.aspx?page $=333$

BSI (2005) Refrigerated display cabinets - part 2: classification, requirements and test conditions. British Standards Institution, London

CCaLC (2011) CCaLC v2.0 software and database. www.ccalc.org.uk

Coca Cola (2010) What's the carbon footprint of a Coca Cola. www.coca-cola.co.uk/environment/what-s-the-carbon-footprintof-a-coca-cola.html

Coop (2011) Environmental product declaration of Acqua Minerale. http://gryphon.environdec.com/data/files/6/8392/epd279 rev2.pdf

DECC (2011) UK climate change sustainable development indicator: 2010 greenhouse gas emissions, provisional figures and 2009 greenhouse gas emissions, final figures by fuel type and enduser. Department of Energy and Climate Change: London. www.decc.gov.uk/assets/decc/Statistics/climate_change/1515statrelease-ghg-emissions-31032011.pdf

Defra (2005) Producer responsibility obligations (packaging waste) regulations 1997 (as amended). Department of Environment, Food and Rural Affairs. www.defra.gov.uk/environment/waste/ producer/packaging/documents/package-datanote.pdf

Defra (2006) Food industry sustainability strategy. Department for Environment, Food and Rural Affairs: London. www.defra. gov.uk/publications/2011/03/28/pb11649-food-industry

Defra (2007) Market transformation programme, BNCR: 36: direct emission of refrigerant gases. Department for Environment, Food and Rural Affairs, London

Defra (2009) Making the most of packaging: a strategy for a lowcarbon economy. Department of Environment, Food and Rural Affairs: London. www.defra.gov.uk/publications/files/pb13189full-packaging-strategy-090624.pdf

EAA (2008) Environmental profile report for the European aluminium industry. European Aluminium Association: Brussels. www.eaa. net/en/environment-health-safety/lca/
EC (2006) Reference document of best available techniques in the food, drink and milk industries. European Commission: Brussels. www.ineris.fr/ippc/sites/default/files/files/fdm_bref 0806.pdf

Ecoinvent Centre (2010) Ecoinvent v2.2 Database. Swiss Centre for Life Cycle Inventories: Dübendorf, Switzerland. www.ecoinvent.ch/

FDF (2008) Our five-fold environmental ambition. Food and Drink Federation: London. www.fdf.org.uk/environment progress report.aspx

Franklin Associates (2009) Life cycle inventory of three singleserving soft drink containers. Franklin Associates, A Division of ERG: Praire Village. http://www.petresin.org/pdf/ FranklinLCISodaContainers2009.pdf

Guinée JB, Gorrèe M, Heijungs R, Huppes G, Kleijn R, van Oers L, Wegener Sleeswijk A, Suh S, Udo de Haes HA, de Bruijn H, van Duin R, Huijbregts MAJ (2001) Life cycle assessment, an operational guide to the ISO standards. Kluwer, Dordrecht, The Netherlands

Gujba H, Azapagic A (2010) Carbon footprint of liquid beverage packaging in the UK. The University of Manchester, Manchester

ILCD (2010) International life cycle database. European Commission Joint Research Centre. 1ca.jrc.ec.europa.eu/lcainfohub/ datasetArea.vm

PE International (2010) Gabi 4.3 LCA software. LeinfeldenEchterdingen. www.gabi-software.com/uk-ireland/index/

IPCC/TEAP (2005) Special report: safeguarding the ozone layer and the global climate system. Intergovernmental Panel on Climate Change: Geneva. www.ipcc.ch/pdf/special-reports/sroc/sroc_full.pdf

Key Note (2003) Packaging (food \& drink) industry 2003. www. keynote.co.uk/market-intelligence/view/product

Key Note (2011) Market report 2011: soft drinks: carbonated and concentrated. S. Walker, K. Hughes, L. Bishop, eds. Key Note Ltd: Richmond upon Thames. www.keynote.co.uk/market- intelligence/view/product/10396/soft-drinks-carbonated-\%26-concentrated?medium $=$ download

Pasqualino J, Meneses M, Castells F (2011) The carbon footprint and energy consumption of beverage packaging selection and disposal. J Food Eng 103(4):357-365

Ramjeawon T (2004) Life cycle assessment of cane-sugar on the Island of Mauritius. Int J Life Cycle Assess 9(4):254-260

Tassou SA, Hadawey A, Marriott D (2008) Greenhouse gas impacts of food retailing. report for Department for Environment, Food and Rural Affairs: London. randd.defra.gov.uk/Document.aspx? Document=FO0405_8189_FRP.pdf

Tesco (2011) www.tesco.com/groceries

US EPA (2011) Ozone layer protection: regulatory programs-leak repair. US Environmental Protection Agency: Washington DC. www.epa.gov/ozone/title6/608/leak.html

van Baxter D (2002) Advances in supermarket refrigeration systems. 7th Int. Energy Agency Conference on Heat Pumping Technologies. May 19-22, 2002 Beijing, China

Vellini M, Savioli M (2009) Energy and environmental analysis of glass container production and recycling. Energy 34(12):2137-2143

Water UK (2009) Sustainability indicators 2008/2009. Water UK: London. www.water.org.uk/home/news/press-releases/ sustainability-indicators-2008-09/sustainability-2009.pdf

Welle F (2011) Twenty years of PET bottle to bottle recycling - an overview. Resour Conserv Recycl 55:865-875 